\title{
切断酸素気流に関する二,三の考察および実験 (第2報)*
}

——予熱炎を伴う場合一

\author{
中西实** \\ Some Considerations and Experiments Regarding to \\ Cutting Oxygen (Report 2)*
}

-- In the case of with preheating flame -

by Minoru Nakanishi**

\begin{abstract}
Regarding to the momentum of cutting oxygen stream, in the report 1 , author described some results of considerations to the phenomena of oxygen stream in the case of without preheating flame. In this paper, cutting oxygen has been considered in the case of with preheating flame.

To study the effect of preheating flame on the momentum of cutting oxygen stream, total head of oxygen stream is measured at various conditions of cutting oxygen pressure and preheating flame, and it has been confirmed that preheating flame is very useful to keep the momentum of cutting oxygen stream. The momentum of cutting oxygen stream is kept most effectively under the conditions as follows.

(1) At about $4 \mathrm{~kg} / \mathrm{cm}^{2}$ of cutting oxygen pressure.

(2) Preheating flame applied is neutral mixture.

(3) At suitable preheating gas flow rate.

(4) Increasing of numbers of preheating orifice. And the best keeping effect is obtained by annular preheating flame.

Relation between momentum of oxygen and cut plate thickness will be described in another paper.
\end{abstract}

\section{1. 緒言}

切断部のスラグ排除に大きな影響を持つと考えられる 切断酸素気流のモーメンタ厶亿関連し，第 1 報1におい てはその粘性の影響を無視しうるものとして, 理論的， 実験的に考察した結果について報告した。

しかし 実際のガス切断気流ではノズルから切断部ま での距離がノズル孔径に比べて大であるため，粘性の影 響を無視することはできず，切断酸素気流は粘性気体の 3 次元噴流として取り报われねばならない。

切断酸素気流については すでに二，三の研究者23334) によって，その超音速域の保持長さが予熱炎の有無に上 り非常に変ることが，シュリーレン法を用いて観察され ている，すなわち 予熱炎を伴う場合の方がはるか原 くなるのである。

しかしてれらと同時に行なわれた範囲の切断実験で はシュリーレンに見られる顕著な差異が 切断結果に はほとんど有意な差を与えなかっだためかか，それ以上

*原稿受付 昭和12年12月12日（昭和41年春季大会発表）

**正 員 (株) 田中裂作所 Member, Tanaka Engineering Works Ltd.
の詳しい検討はなされなかった，

箖者はてれまでに得られている予熱炎と切断板厚之の 関係らなどからての影響を無視し得妨すの上考元，予熱 炎がある場合とない場合について切断酸素気流の総圧を 湘定し，酸素気流のモーメンタム変化に及ぼす予熱炎の 影響を明らかにした。

本稿の内容を要約するに，まず測定の対象となる 3 次 元噴流の基本概念を明らかにし，ついで実験装置おょび 湘定方法を示した後, 切断酸素王力, 予熱炎の混合比, 予熱炎の大きさ，切断火口の予熱孔数などが気流のも一 メンタム保持に及ぼす影響について实験データを示し， 考察を加えている.

\section{2 ． 3 次 元 噴 流}

切断酸素気流のごとく 円形断面のノズルから静止気 体中八隫出する気流を 3 次元啐流之上ぶが，乙れの取り 扱いについては気体力学の分野でもその解明には実験を 必要としている。

噴流之静止気体との間には大きな速度差が存在する。 この速度差と粘性による摩擦力のため静止気体が䠣流中 にまき込まれ，噴流は Fig. 1 および Photo. 1 に示すで 


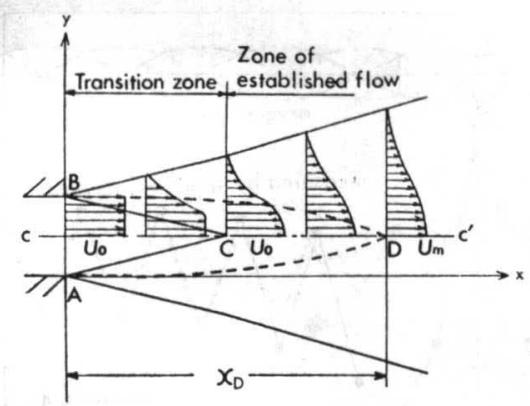

Fig. 1 Structure of jet

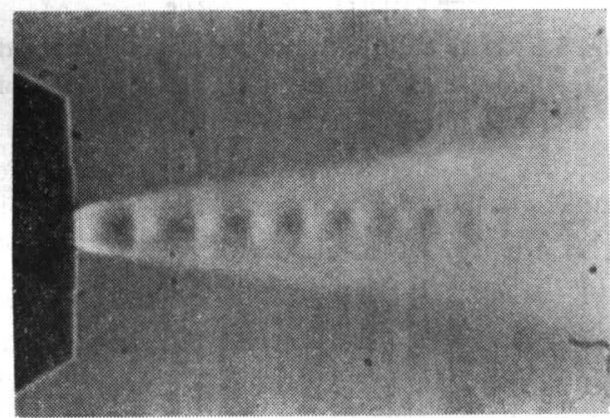

Photo. 1 Schlieren photograph of jet

とく次第に拡散し，そのモーメンタムを減少する*1*2.

したがってての摩擦力の大きさによりモーメンタムの 減少のし方は大いに変るむの之考えられる.

摩擦力 $\tau_{0}$ は一般的には次のような形で表わせるとさ れている6).

$$
\begin{aligned}
& \tau_{0}=\rho \varepsilon \frac{\partial u}{\partial y} \\
& \text { ここに } \quad \rho: \text { 気体の密度 } \\
& \varepsilon: \text { 乱流拡辐係数 }
\end{aligned}
$$

この式における $\varepsilon$ は層流における動粘性係数 レに相当 するが, $\nu$ が物質による一定定数であるのに比べ， $\varepsilon$ は 場所または問題により異なるもので物理的実体が明確で はない。

したがって本稿で問題とするような噴流の周囲に燃焼 が伴うような場合についてはデータが皆無で, $\tau_{0}$ は計算 することができず, その影響は実験によって直接的に求 められなければならない.

ただし乱流境界層での摩擦力は密度に対する温度の効 果が主となる7)といわれているので, 予熱炎を伴う場合 は $\tau_{0}$ が小さくなることが予測される.

次に噴流の構造を考えると, Fig. 1 亿示すように基本

*1 まき迈まれた気体も含んで噴流と考えるときはモーメンタムは不変 である.

*2 Photo. 1 は应散の模様を見やすくするため, 空気中にヘリウムを 嘪出したときのシュリーレン写真である。
的には二つの領域が存在する 流速 $\mathrm{U}_{m}$ が噴出時の流速 $\mathrm{U}_{0}$ 飞等しい領域（遷移領域 Transition zone) と, それを過ぎた領域 (発達域 Zone of established flow) とである*3.

第 1 報で述べたように，切断酸素気流ではストレート ノズルからの噴流といえどあ一般にノズル近傍の $\mathrm{U}_{m}$ は 音速を超しているので, てのような場合にはさらに点線 ADB で囲まれるような第 3 の領域を考えることができ る. すなわち点線 $\mathrm{AD}$ および $\mathrm{BD}$ は流速が丁度音速に 等しくなる線で, 領域 ADB 内では局所的に流速, 静 圧などが変化し, シュリーレン的にはそろばん珠状の疎 密模様が現われる.

本稿における総圧測定実験においては 噴流の軸心 $\mathrm{C}$ $\mathrm{C}^{\prime}$ に沿ってピト一管を移動させ, 圧力計の指示 $P_{02}$ を 読みとったが，第一報で述べたごとく，ノズル出口から $\mathrm{D}$ 点までの区間では $P_{02}$ は真の総圧 $P_{01}$ とは等しくな く, 異った条件でのデータの直接的比較が困難になる. したがって本稿ではてれを容易にするために, データの 比較値として $P_{02}=P_{01}=1.89 \mathrm{~kg} / \mathrm{cm}^{2}$ になる D 点の距 離 $x_{D}$ を採用することにした*4,*5.

\section{3 . 実験装置および測定方法}

総圧の測定は Fig. 2 および Table 1 に示す実験用 火口について行ない, Fig. 3 に示すでとき実験装置を用 い 火口距離を変化させ, ピト一管に取りつけられた圧 力計の指示 $P_{02}$ を読みとった.

\begin{tabular}{|c|c|c|c|c|}
\hline \multirow{2}{*}{ Nozzle } & \multirow{2}{*}{$\begin{array}{c}\text { Cutting orifice } \\
\qquad d_{1}(\mathrm{~mm})\end{array}$} & \multicolumn{3}{|c|}{ Preheating orifice } \\
\hline & & $d_{2}(\mathrm{~mm})$ & nos. & $\begin{array}{l}\text { P.C.D } \\
\text { (mm) }\end{array}$ \\
\hline A & 1.6 & 1.1 & 1 & 7.8 \\
\hline B & " & $"$ & 2 & $"$ \\
\hline C & $"$ & $"$ & 4 & $"$ \\
\hline $\mathbf{D}$ & $"$ & $"$ & 6 & " \\
\hline $\mathbf{E}$ & $"$ & $"$ & 8 & " \\
\hline $\mathbf{F}$ & " & \multicolumn{3}{|c|}{ annular preheating type } \\
\hline G & $\begin{array}{l}\text { Throat dia. } 1.6 \mathrm{~mm} \text {, } \\
8 \mathrm{~kg} / \mathrm{cm}^{2} \text { Divargent } \\
\text { nozzle }\end{array}$ & 1.1 & 6 & 7.8 \\
\hline
\end{tabular}

ただし 予熱炎を伴わないときは測定を容易にするた

Table 1 Used cutting nozzles

*3 噴流と静止気体が同一気体の場合には，発選域における中心部の流 速 $U_{m}$ は距離 $x$ に反比例して诚少することが明らかにされてい 39).

$*_{4}$ 昭和 41 年度春季講演会 (本誌第 35 巻第 2 号 p. 102) に括いては $P_{02}$ がノスル入口化力 $P_{0}$ の $1 / 2$ になる距崔 $x$ を用いて整理したが，考 察の結果 $x_{D}$ の方が物理的意味が明確になると考えた。

${ }^{*}{ }_{j} P_{02}=P_{01}=1.89 \mathrm{~kg} / \mathrm{m} 2$ になるのは第 1 報 (9) 式から明なごと く, $\gamma=1.40$ なる気体に対するもので，本稿の場合のようにカスの 組成が明らかでない場合には戦密には正しくないが，D点の成分も $\gamma=1.40$ として取扱った. 


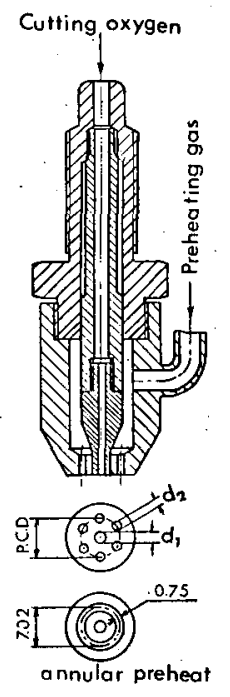

Fig. 2 Gross section of nozzle

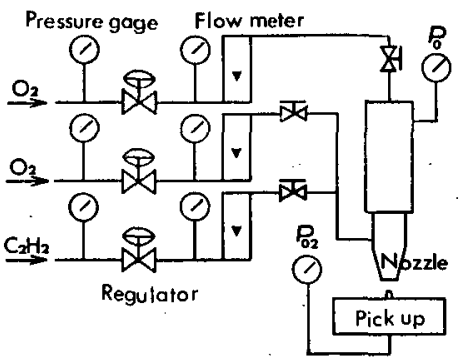

Fig. 3 Total head measuring system

めに 第一報で用いたのと同じ注射針をピト一管として 用い，予熱炎を伴うときはその溶損をさけるために

Fig. 4 に示すごとき水冷式ピックアップをピト一管とし て用いた。

なお ピトー管の形状の差買が測定結果に及ぼす影響 をしらべるために，ノズル孔径 $1.6 \mathrm{~mm}$ のストレートノ ズルに $6 \mathrm{~kg} / \mathrm{cm}^{2}$ の $P_{0}$ をかけ，噴流軸心部（Fig. 5 の $\left.\mathbf{c} \mathbf{c}^{\prime}\right)$ の $P_{02}$ を雨ピト一管を用いて測定し，その値を比 較した.

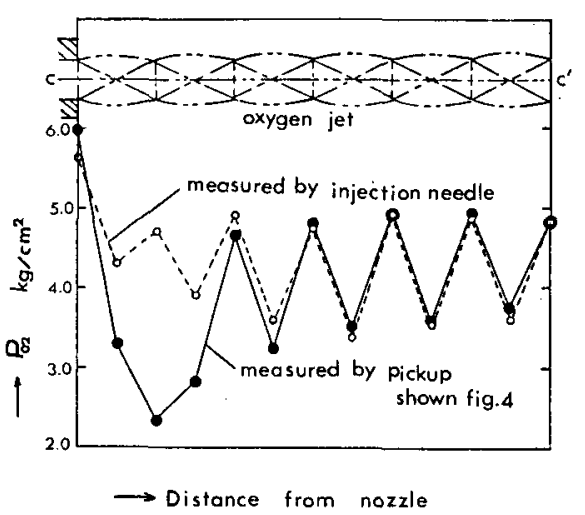

Fig. 5 Relation between measured total head and nozzle distance by means of two types of pito tube

その結果は Fig. 5 に示すごとくで，白丸は注射針， 黒丸はピックアップによる値であり、鎖線で画く曊流は シュリーレンによって観測したすのである。.Fig. 5 から わかるように 笨 $1 ， 2$ 波の近傍では測定值に相当な差 が出ているが，第 3 波以降ではその差はほとんどなく，

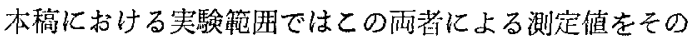
まま此較してもよいととを確認した。

また压力の表示は第 1 報の場合と同じく絶対压力を用 い，てれを $\mathrm{kg} / \mathrm{cm}^{2}$ で表わした。

\section{4.実験結果および考察}

Fig. 6 は実験結果の一例を示するので，D/ズルを用 い, $P_{\mathrm{n}}=4 \mathrm{~kg} / \mathrm{cm}^{2}$ の場合のノズル距離 $\mathrm{X}$ と噴流軸心に 沿う測定総压 $P_{02}$ との関係である．点線で示すデータは 予熱炎を伴わない場合であり，実線で示すあのはアれチ レン・酸素各 $2000 \mathrm{l} / \mathrm{h}$ の予熱奖を伴う場合である。

図から一目にして明らかなごとく，切断酸素気流は子 熱炎を伴うことによって，そのモーメンタムをノズルか らはるかに遠い距離まで保持している，すなわち 切断 酸素之炎との境珚では摩擦力が非常に小さくなるととが わかる。

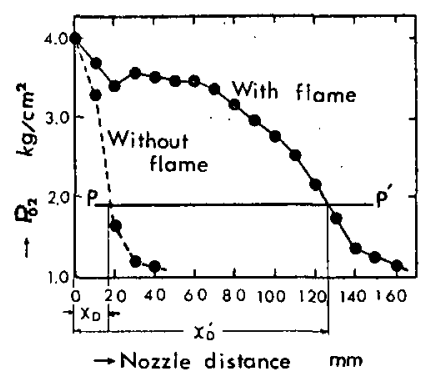

Fig. 6 Measured total head and nozzle distance

Fig. 4 Water cooled total head pick up 
図中 $\mathrm{X}$ 軸に平行に引かれた直線 $\mathrm{PP}^{\prime}$ は $P_{02}=1.89 \mathrm{~kg} /$ $\mathbf{c m}^{2}$ を示すところで，噴流は丁度この線で音速になる。 したがって総圧線とての線が交わる D, D' が Fig. 1 の D点に相当し, これらの点の $\mathrm{X}$ 座標 $x_{D}, x_{D^{\prime}}$ が Fig. 1 の $x_{D}$ に相当するととになる.

\section{1 切断酸素圧影響}

Fig. 7 は D ノズルを用い，予熱炎なしで $P_{0}$ の值を $2,3,4,5,6 \mathrm{~kg} / \mathrm{cm}^{2}$ に変化させた場合の実験結果を示す あので, Fig. 6 の場合之同様ノズルから非常に近い距離 で $P_{02}$ は急激に減少している. しかし $x_{D}$ はFig. 9 の 点線で示すごとく, $P_{0}$ の増加に伴い增加している.

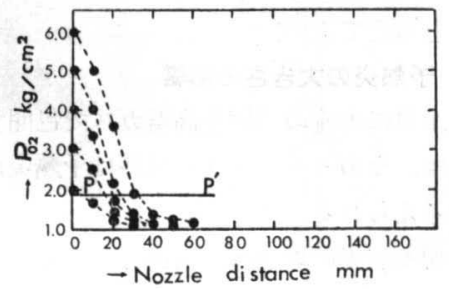

Fig. 7 Relation between nozzle distance and measured total head $\left(P_{02}\right)$ for various nozzle entry pressure $\left(P_{0}\right)$ without preheating flame

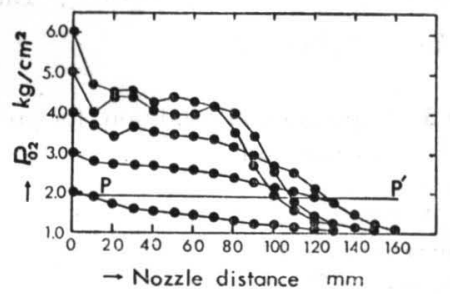

Fig. 8 Relation between nozzle distance and $P_{02}$ for various $P_{0}$ with preheating flame

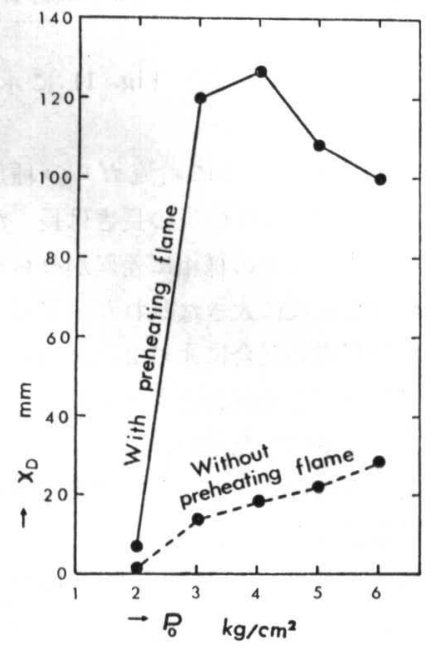

Fig. 9 Effect of $P_{0}$ on $\mathrm{X}_{\mathrm{D}}$
Fig. 8 は同上の条件に, 酸素・アセチレン各 $2000 l / \mathrm{h}$ の予熱炎をつけた場合で, 各圧力ともモーメン゙タムは予 熱炎のない場合に比べてはるかに遠くまで保持されてい る.

しかし $P_{0}$ と $x_{D}$ との関係は予熱炎のない場合と異な り, $x_{D}$ は $P_{0}=4 \mathrm{~kg} / \mathrm{cm}^{2}$ 近傍で最高になっている.

このように 予熱炎を伴う場合, $P_{0}$ を大にするとかえ って気流のモーメンタムが減衰する理由は次のように考 えることができる.

予熱炎の 2 次酸素は大気から供給されるが, 切断酸素 がある場合はこれからあ供給される。したがって $P_{0}$ が 増大して酸素量が増加すると, 2 次燃焼に供給される酸 素も増加し, その結果 2 次燃焼が短い距離で完了し, 切 断酸素気流はノズルに近い所で温度の低い大気中に露出 され 摩擦が増加するととになる。

Photo. 2 の $a \sim g$ は $P_{0}$ を変えた場合の状態を示した

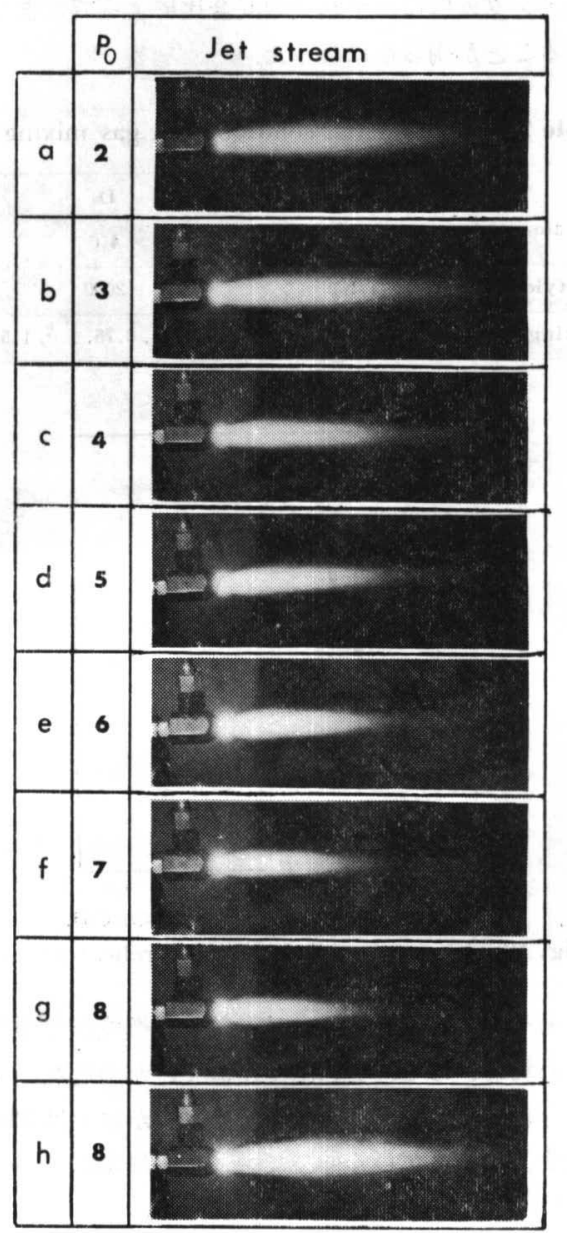

Photo. 2 Effect of nozzle entry pressure $P_{0}$ on stream appearance 
あので, $P_{0}$ の増加に伴い炎の長さが減少しており, こ れらの写真からも上述の理由が容易に推測できる.

切断酸素加らの 2 次酸素量の増大は単に $P_{0}$ の増加に 伴う切断酸素流量の絶対量の増加に比例するものではな く,むしろ $P_{0}$ の増加によって生じる気流の乱れに関係 があるあのと考えられる.

Photo. 2 の $h$ はこれを証明するあのであって, 最小 䉼面径が D ノズルに等しいダイバーゼントノズル $(G)$ に $a \sim g$ 之同一の予熱ガス量を流し $P_{0}=8 \mathrm{~kg} / \mathrm{cm}^{2}$ に したもので, 酸素の絶対量は $g$ と全く等しいにあかかわ らず, 炎の長さは $\mathrm{g}$ に比へて非常に長くなっている.す なわち乱れの少ない切断酸素気流では その流量が同一 であ炎は長くなるのである.

\section{2 予熱炎の湿合比の影響}

予熱炎の混合比が切断酸素のモーメンタム保持に与元 る影響をしらべるために Table 2 に示すでとき条件で 実験を行なった. 実験結果は Fig. 10 に示すでとくで, モーメンタム保持は予熱炎の混合比によって大きく影響 されることが明らかになった。

Table 2 Experimental conditions for gas mixing ratio

\begin{tabular}{c|c}
\hline \multicolumn{1}{c|}{ Nozzle } & D \\
\hline $\begin{array}{c}\text { Nozzle entry pressure } P_{0} \\
\left(\mathrm{~kg} / \mathrm{cm}^{2}\right)\end{array}$ & 4.0 \\
\hline Acetylen flow rate $(l / \mathrm{h})$ & 2000 \\
\hline Mixing ratio $\left(\mathrm{O}_{2} / \mathrm{C}_{2} \mathrm{H}_{2}\right)$ & $0,0.25,0.5,0.75,1.0,1.5,2.0$ \\
\hline
\end{tabular}

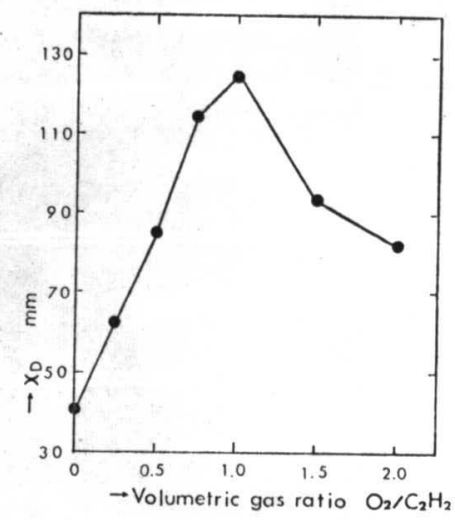

Fig. 10 Effect of mixing ratio of preheating flame

アセチレン過剩炎の場合は予熱炎の燃焼がじゅう分に 行なわれないので, 炎の温度が低く, かつ遊離の炭素分 子が存在するために摩擦が多くなり見かけ上は Photo. 3 に示すように炎が長く伸びても, 切断酸素のモーメンタ ムは早く減少するすのと考えられる。

酸素過剩炎で保持効果が悪くなるのは燃燒が早く完絬 し，切断酸素圧が高い場合と同様な現象になるからであ

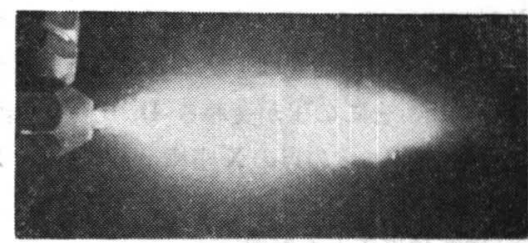

Photo. 3 Stream appearance applying nonmixed acetylene flame

る.

切断酸素のモーメンタム保持能力が中性炎近傍で最大 となるこの現象は 実際の切断において 炎温度の高い 酸素過剩炎よりもむしろ中性炎が広く使われるととと関 係があると考えてよい，

\section{3 予熱炎の大きさの影響}

予熱炎が単に噴流の周囲を高温ガスで包柬するだけの 効果ならば，そのモーメンタム保持は予熱炎が大である 程よいと考えられる.

しかし切断酸素の場合は 前述のごとく, その一部が 2 次炎の燃焼に関与し周囲ガスの温度分布その他に影響 を与えるような別の効果が現われるととが考えられるの で, 予熱炎が大であればある程よいというわけにはいか ない，てのととを確めるために，噴流ガスとして酸素お よび窒素を用い, 予熱炎の大きさをかえ, Table 3 に示 すごとき条件で実験を行なった。

Table 3 Experimental conditions for preheating gas flow rate

\begin{tabular}{l|c}
\hline \multicolumn{1}{c|}{ Nozzle } & F, (G) \\
\hline Nozzle entry pressure $P_{0}$ \\
\hline Mixing ratio $\left(\mathrm{O}_{2} / \mathrm{C}_{2} \mathrm{H}_{2}\right)$ & 4.0 \\
\hline Gases for jet & 1.0 \\
\hline Total gas flow rate $(l / \mathrm{h})$ & $600,1000,2000,3000,4000$ \\
\hline
\end{tabular}

実験結果は Photo. 4 および Fig. 11 に示すごとく である。

Photo. 4 からわかるように噴流ガスの種類にかかわ らず予熱ガス量の増加に伴い炎の長さは長くなっている が, 小流量の範囲ではその様相に差異がみられる，窒素 噴流の場合には 2 次炎に大きな乱机生じ炎は短くなっ ている．てれは窒素の混合により 2 次炎の相当部分が未 燃焼のまま温度低下したためと考えられる。

予熱炎が大になるにしたがい, 噴流は均一に2 次炎 で包囲されるようになる。したがって窒素の場合には Fig. 11 に見るごとくガス量の増加に伴いモーメンタム の保持効果は大となり, 予熱量 $2000 \mathrm{l} / \mathrm{h}$ 以上では雲囲 気が一様な高温ガスになったのと近い効果を与えてい る. しかし保持効果は酸素に比べてはるかに小さい. 


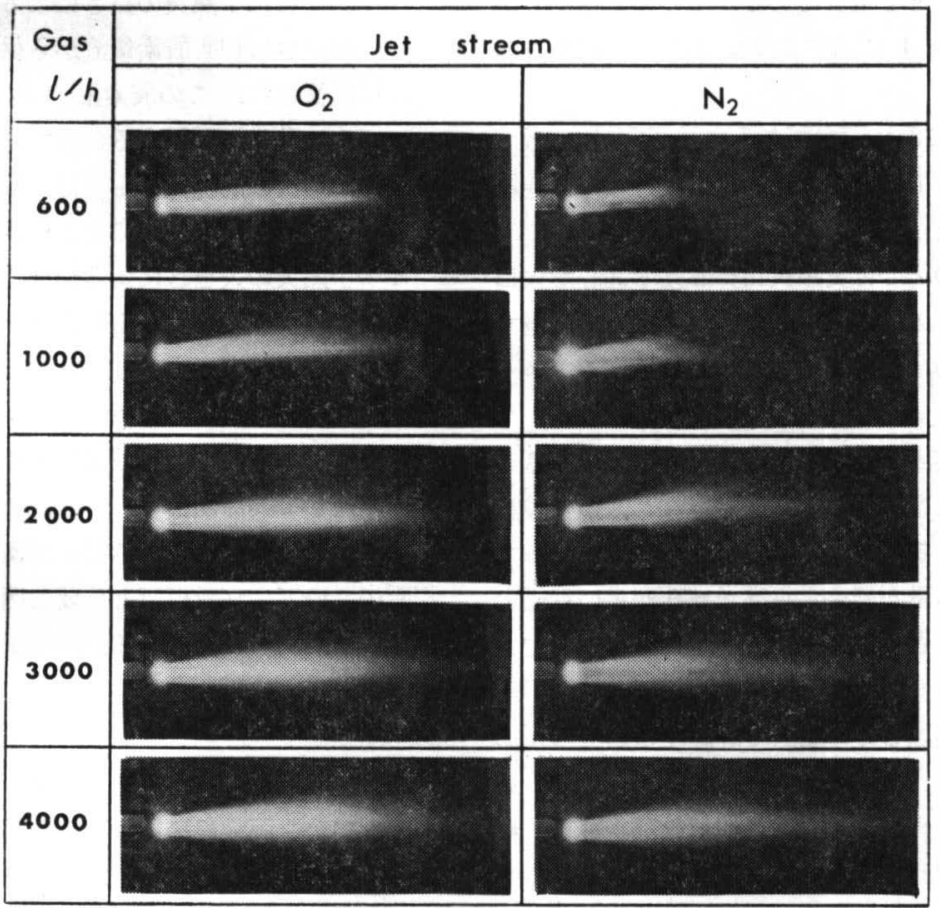

Photo. 4 Effect of preheating gas flow and jet gas on stream appearance

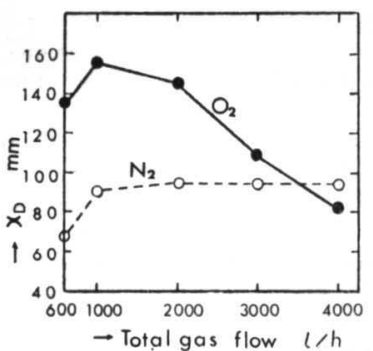

Fig. 11 Effect of total gas flow and jet gas on $x_{D}$

酸素の場合にはその周囲で急激な燃焼がおこっている ことが観察され, その結果周囲の気体温度が上昇し, 摩 擦が減少して, モーメンタムの保持効果が窒素に比べて よくなるあのと考えられる.

予熱炎がある值以上大になると反って保持効果が悪く なる理由はよくわからないが, 予熱ガス量の増加に伴い 燃焼度合またはその状態に変化が生じモーメンタム保持 効果が変るあのと考えられる.

\section{4 予熱孔数の影製}

切断酸素気流のモーメンタム保持が 気流周囲の燃焼 気体の分布に影響されることが明らかになったが，この ことは実用上の火口を考える上に非常に重要なことであ る.

たとえば 切断酸素孔に対する予熱孔の配置がこれに
Table 4 Experimental conditions for numbers of preheating orifice

\begin{tabular}{|c|c|}
\hline Nozzle & $A, B, C, D, E, F$ \\
\hline Nozzle entry pressure $P_{0}$ & 4.0 \\
\hline Mixing ratio $\left(\mathrm{O}_{2} / \mathrm{C}_{2} \mathrm{H}_{2}\right)$ & 1.0 \\
\hline Acetylens flow rate $(l / h)$ & 1000 \\
\hline
\end{tabular}

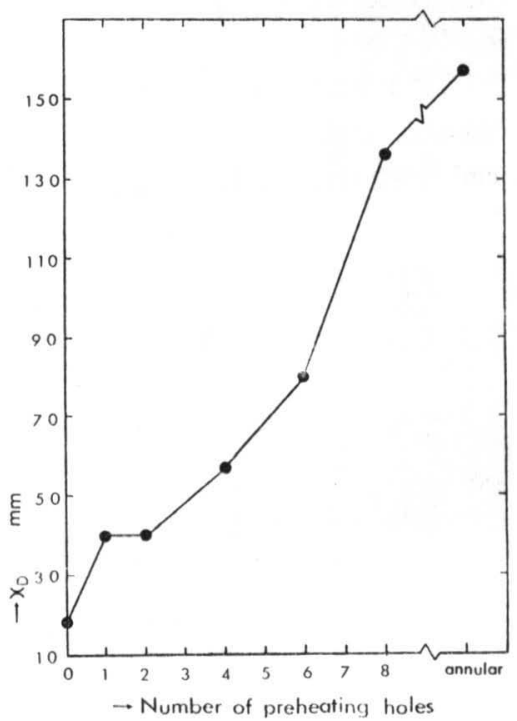

Fig. 12 Effect of numbers of preheating holes on $x_{D}$ 
与える影響を知るてとあ重巽である。乙の影響を明らか にするために Table 4 に示すような条件で皮験を行な った.

慜験結果は Fig. 12.に示すでとくで，予熱孔の数が 多くなるにしたがって，その保持効果は大となり，連続 㴖形のるので最大となる。

予熱孔数が 1 孔の場合は実用火口における異心形火口 に相当し, 連続满形の.屯のはフランス式火口に相当す る、また 6 孔のものは.自動切断などに用いられるスエー ジ式 1 体火口に多く見られるすのである。

この実験結果と実際の切断を直接定量的に比較するこ 亡は 切断の場合には固体の切断满が存在し，加酸素 が鉄の燃烧に使われるなど大いに状態が異るため困難で はあるが，予熱ガス量が同一ならば予熱孔が多い程最大 切断板厚が增加するという事実占が定性的には説明でき るあのと考えている、

またこの他にも笑際のガス切断で経験するいくつかの 現象を説明できる。

たとえば 異心形火口の場合には切断火口を被切断材 に近接せしぬねば切断性が悪くなる事実，火口高さを一 定に保古難い手動切断に扔いて 6 孔形スエージ火口より フランス式火口の方が使いやすい事实などである。

\section{5 . 結}

論

本研究は予熱炎が断断酸素気流のモーメンタム保持に 及ぼす影響を知るために行なったもので，数種類の实験 用火口を製作し，切断酸素仼力，予熱炎の混合比，予熱 ガス量, 予熱孔数などをかえ 切断酸素気流の総庄を测 定し，次のような結論を得た。

1）予熱炎は切断酸素気流のモーメンタ厶保持に有効 に働らく。

2）予熱炎による切断酸素のモーメンタム保持効果は 切断酸素生力に関しては, ノズル入口圧力 $P_{0}=4$ $\mathrm{kg} / \mathrm{cm}^{2}$ 近傍で最高になる。(ただしストレートノズ
ル）てれは予整炎の長さによるあのであるが，予熱 炎の長さは切断酸素気流加ら供給される2 次酸素量 に影響され，乙の酸素量が $P_{0}$ ，の変化よる切断酸素 気流の乱れ関係するからである。

3）予熱资の混合比の影響は, 酸素・アセチレン混合 比 1：1（中性炎）の之き保持効果最大となる.

4 ）予熱炎の大きさによる保持効果は 喷流が窒素の 場合は予熱炎が大なる程よいが, 酸素の場合は予熱 炎が適当な大きさのとき最大らなる。

5) 予熱孔数による保持勃果は，数の多い程よく，連 続溝形予熱孔のとき最大であり，てれは実用火口と 関連して與味がある。

なおこの予熱炎による切断酸素の保持効果は実際の 切断において，切断板厚之重要な関係を持つが，乙れに ついては別禞にて報告する。

\section{謝辞}

本研究の遂行にあたっては大阪大学工学部 安藤弘 平，西口公之両教授の御指導之有益なる御助言を得た， 誌して感謝の意を表するしだいである.

\section{参考 文 献}

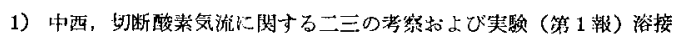
学会誌 投稿中

2) A. Hilpert, Investigation on Phenomena of Arc Welding and Gas Cutinig by Slow Motion Picture, W.J. July 1933

3) R.L. Stecker et al., Fundamental Concepts of Oxygen Cutting, W.J. March, 1957

4) W. Scheicher, Untersuchungen des Schneidsauerstoffstrahls im Verbindung mit der Riefenbildung Beim Brennschneiden, Schweissen und Schneiden, 1964, 7

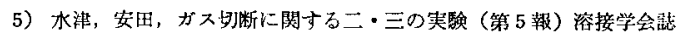
Vol, 30, No. 10 (1961)

6) 谷一郎, 流孔学, 岩波書店, 1967, p. 138

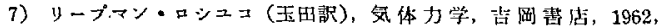
p. 375

8）星崎，原，純流件琹子入䢹，日测工業，昭12，p，99

9) H. Schlichting, Boundary Layer Theory, McGraw.Hill, 1955 , p. 596 